\title{
STUDY OF MORPHOLOGICAL AND QUALITATIVE PLANT TRAITS AGAINST THE INFESTATION OF Chilo infuscatellus $\mathrm{L}$. (PYRALIDAE, LEPIDOPETRA)
}

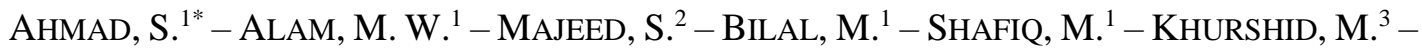 \\ SARWAR, M. ${ }^{1}-$ SHAFEEQ, T. ${ }^{1}-$ SALMAN, S. ${ }^{4}-$ ALI, Q.$^{5 *}$ \\ ${ }^{1}$ Institute of Agricultural Sciences, University of the Punjab Lahore, Lahore, Pakistan \\ ${ }^{2}$ Department of Entomology, University of Agriculture Faisalabad, Pakistan \\ ${ }^{3}$ Institute of Biochemistry and Biotechnology, University of the Punjab Lahore, Lahore, \\ Pakistan \\ ${ }^{4}$ Department of Plant Breeding and Genetics, Gomal University, Dera Ismail Khan, Pakistan \\ ${ }^{5}$ Institute of Molecular Biology and Biotechnology, University of Lahore, Lahore, Punjab, \\ Pakistan \\ *Corresponding authors \\ e-mail: shahbaz.iags@pu.edu.pk, saim1692@gmail.com
}

(Received 22 $2^{\text {nd }}$ Feb 2019 ; accepted $8^{\text {th }}$ Apr 2019)

\begin{abstract}
The Chilo infuscatellus (Pyralidae, Lepidoptera; Snellen) caused significant losses in production and quality of sugarcane in Pakistan. The deficiency of easily discrete morphological and quantitative characters makes it remarkable to identify these characters in pest management. Present study; investigates the impact of morphological and quality traits of pest infestation during different stages of plant growth. Results revealed that varieties US-312, 1491, 718, 133 and CPF-246 performed better in terms of brix, POL, CSS, fiber, recovery, carbohydrates, moisture and fat contents percentage. Correlation values of different varieties in terms of qualitative factors were positive and significant. All plants traits in terms of qualitative factors including plant girth $(\mathrm{cm})$, leaf area $(\mathrm{cm})$, leaf sheath hairiness $\left(\mathrm{cm}^{2}\right)$ and leaf thickness (mm) showed positive and had highly significant correlation with pest infestation. The coefficient of determination value $\mathrm{R}^{2}=0.821$ was obtained by computing brix, fiber contents, POL and CCS factors mutually from multivariate regression models. It was concluded, that morphological and qualitative plant factors could be helpful for management of sugarcane shoot borer.
\end{abstract}

Keywords: Lepidopteran pest, management, plants, shoot borer, sugarcane

\section{Introduction}

Sugarcane (Saccharum officinarum) is a perennial, tropical and subtropical crop cultivated in various regions of the world (Kfir et al., 2002). It is grown between tropical and sub-tropical climate (North latitude $=350 \mathrm{C}$ and South latitude $=350 \mathrm{C}$ ) around the world. In Pakistan, sugarcane is a cash as well as industrial crop and grown on an area of 1217 thousand hectares with 73.6 million tons' annual production (Anonymous, 201617). The Pakistan sugar industry is second largest industry of the country after textile having GDP of $0.7 \%$ (Anonymous, 2016-17). Being a cash crop, it provides a huge quantity of raw material to sugar industry. In Pakistan, the average sugarcane yield is much lower than the other growing countries of the world (Kumarasinghe, 1999). There are many factors which are responsible for low sugarcane yield of sugarcane but most important factors are pests, in which borers are most damaging. Among borers, sugarcane shoot borer (Lepidoptera: Crambidae) is considered as the most damaging and injurious 
pest of sugarcane that resulted in reduced quality and quantity of cane sugar (Zia et al., 2007; Sabir et al., 2014). The molecular study was described to identify $C$. infuscatellus through PCR by using barcode region CO1sequence between the sugarcane shoot borer and four other species of sugarcane. A 285bp fragment was effectively amplified from all stages of different geographical population (Wang et al., 2017). It has been reported that sugarcane yield had been decreased from $20.78 \%$ to $57.9 \%$ in most parts of the world including Pakistan (Anwar et al., 2004). The injured plants attacked by this pest produce dead hearts during growing season before till the formation of canes and such plants do not grow further (Shahid et al., 2007). Yield losses could be minimized by planting some resistant varieties i.e. (R570) instead of susceptible i.e. (R579) (Goebel et al., 1999). Knowing the morphological and qualitative plant factors are helpful to examined the relationship between pest infestations (Khaliq et al., 2005). Therefore, objective of the present study was to find out the impact of morphological and quality traits of sugarcane against the pest infestations.

\section{Materials and Methods}

The experiment was conducted field area of University of Agriculture, FaisalabadPakistan under randomized complete block design (RCBD). The climate is very hot in summer up to $45^{\circ} \mathrm{C}$ while winter, it is cold up to $22^{\circ} \mathrm{C}$. The average rainfall is very low as compared to other areas of Punjab. After the preliminary screening, nine sugarcane varieties including US-676, US-133, US-312, SPF-234, US-1491, US-824, CPF-246, US718 and CPF-237 were selected.

The plot size was kept $5 \times 10 \mathrm{~m}^{2}$ and the experiment was repeated thrice. There were five rows in each plot for each variety. Middle three rows were selected for recording the data during preliminary screening. All the recommended agronomic practices (hoeing, earthing up, balance use of fertilizer and irrigations) were applied. The observations were taken at weekly intervals. The number of total internodes and infested internodes were counted separately from each cane and the borer infestation percentage was calculated by the following formula.

$$
\text { Borer Infestation }(\%)=\frac{\text { Number of Infested Internodes }}{\text { Number of total Internodes }} \times 100
$$

\section{Morphological Factors}

\section{Leaf thickness}

Five plants were selected randomly from each block. The leaves were cut from the upper, middle and lower part of the plant and measured in $(\mathrm{mm})$ to determine the leaf thickness with help of a binocular microscope (Made by Omax).

\section{Leaf Area}

Ten plants from each block were selected randomly. Three leaves one from top, middle and bottom portion of the sugarcane was taken and measured in $(\mathrm{cm})$. Leaf area was measured with help of LI-30000, a portable leaf area meter. 


\section{Leaf Sheath Hairiness}

Five canes were selected randomly from each block. Each leaf sheath was examined from three different places by a phase contrast stereo microscope (Made by Euromax). The number of hairs was counted in one $\left(\mathrm{cm}^{2}\right)$.

\section{Stalk Girth}

For stalk girth, 10 cane samples from each block were randomly selected from three different places upper, middle and lower from each the sugarcane sample was selected for stalk girth. The stalk girth was measured with help of ordinary measured $(\mathrm{cm})$ using a measuring tape.

\section{Qualitative Factors}

\section{Analysis of Sugar Cane}

Analysis of cane includes brix \%, POL\%, CCS\% and fiber\% was determined. On the basis of these qualitative factors, the maturity of a cane variety was decided. When a cane variety attains brix (20\%), POL (18\%) and purity (80\%) in any month from October to March, it was considered matured.

\section{Juice Extraction}

The representative cane sample consists of 8-10 numbers of canes which were passed through cane crusher to get juice. The extracted juice was collected into a plastic bucket.

\section{$\operatorname{Brix}(\%)$}

For the brix determination juice 400-500 $\mathrm{ml}$ was taken. The Brix was recorded through brix hydrometer (Made by Yuyao Hjiyi Electronics) calibrated at $200^{\circ} \mathrm{C}$. When temperature of juice was above $200^{\circ} \mathrm{C}$, then a correction factor was added (47) into brix reading, if the temperature was below $20^{\circ} \mathrm{C}$, then correction factor was subtracted. Hydrometer was dip to down the movement into cylinder after 25 minutes, after that juice temperature was come at room temperature.

\section{POL (\%)}

Two hundred $\mathrm{ml}$ of extracted juice was placed into a flask and $5 \mathrm{~g}$ basic lead acetate was added and shaken well. The juice was filtered into a volumetric flask through a filter paper and injected into $200 \mathrm{~mm}$ polarimeter tube to record the POL reading. The POL reading was the measurement of the angle of rotation of dextrorotatory substances. Polarity worked on the principle that under certain standard conditions i.e. standard tube length, standard solution concentration and standard room temperature when a polarized light was passed through that sugar solution, then substances present rotate light at a definite angle. The measurement of that angle of rotation was POL reading. Calculations were done by following the formula of Payne (1968).

\section{Commercial Cane Sugarcane (CCS)}

The commercial cane sugar percentage (CCS\%) was calculated by using following formula (Meade and Chen, 1977). 
where, $0.4=$ multiplication factor, $0.74=$ crusher factor .

\section{Fiber Contents}

Fiber contents were determined by collecting 12 canes, top internodes of three canes, and middle portion internodes of next three canes while lower internodes of remaining three canes were cut, separated, mixed and fed to the Jaffco cutter grinder (Jeffress Engineering). This instrument was not only cuts and grinds but also minces the internodes. $500 \mathrm{~g}$ sample of this grinded bagasse was weighed and pressed less than 2000 pound per square inches on a hydraulic press for two minutes. The fresh fiber cake was then prepared and weighed and dried in oven for 12 hours at $1000^{\circ} \mathrm{C}$. Percentage fiber was calculated using following formula (Payne, 1968).

$$
\text { Percent fiber }=\frac{\text { Weight of dried sample }}{\text { Weight of sample (gram) }} \times 100
$$

\section{Sugar Recovery}

It was calculated by multiplying CCS with a constant factor 0.94 . Actually, to convert brown sugar into white sugar; $6 \%$ white sugar was also lost, therefore, a constant factor used. Sugar recovery was calculated with the following formula (Mathur, 1981).

$$
\text { Recovery }=\text { B.H.E. } \times \text { B.H.R. } \times \text { POL } \% \text { juice } \times \text { Juice extraction } 0.94
$$

where

- B.H .E = Boiling House Efficiency

- B.H.R. = Boiling House Recovery i.e. B.H.R. = S $(\mathrm{J}-\mathrm{M})$

$\mathrm{J}(\mathrm{S}-\mathrm{M})$, here

- $\mathrm{S}=$ Sucrose purity

- $\mathrm{J}=$ Juice purity

- $\mathrm{M}=$ Molasses purity

Weight of sample + wt. lost during preparation.

\section{Fat Contents}

Fat was determined by taking 50 grams of crushed, oven dried sample in thimble plugged with cotton using n-hexane as solvent in a Soxhlet apparatus (Made by Corning Life Sciences) and heating the flask containing solvent. The fat extraction in Soxhlet was done by adjusting 3 drops of $n$-hexane per second till complete drawing of fat from sample. Then the content of the receiving flask was transferred to a pre weighed Petri dish and dried till to constant weight was obtained. Fat calculated with help of following formula (AOAC, 1996):

$$
\text { Fat }(\%)=\frac{\text { Weight of fat in sample }(\mathrm{gram})}{\text { Weight of sample }(\mathrm{gram})} \times 100
$$




\section{Moisture Content}

For the determination of moisture, 50\% sample from each variety was taken in petri dishes dried in hot air oven at $70^{\circ} \mathrm{C}$ for 24 hours, till constant weight. The moisture contents were calculated by the formula:

$$
\text { Moisture(\%) }=\frac{\text { Moisture losses }}{\text { Weight of original sample }} \times 100
$$

Moisture losses $=$ Weight of original sample - Weight of oven dried sample .

\section{Carbohydrates}

Carbohydrate contents were determined by following formula:

$$
\text { Carbohydrate }(\%)=100-\text { crude protein }+ \text { fats } \%+\text { crude fiber }+ \text { ashes }
$$

Statistical analysis

The data were analysed by analysis of variance (ANOVA) and means were compared by the Tukey's HSD test $(\mathrm{P} \leq 0.05)$ using software Statistix 8.1.

\section{Results}

\section{Role of Physico-Morphic Factors on the Shoot Borer Infestation}

The maximum leaf sheath hairiness $\left(102 \mathrm{~cm}^{2}\right)$ was recorded in CPF-246 and variety SPF-234 showed minimum leaf sheath hairiness $\left(53 \mathrm{~cm}^{2}\right)$. The maximum leaf thickness $(0.660 \mathrm{~mm})$ was found in variety CPF-246 while the variety CPF-237 showed minimum leaf thickness $(0.583 \mathrm{~mm})$. The maximum plant girth $\left(5.4 \mathrm{~cm}^{2}\right)$ in variety US-824 and the variety CPF-246 showed minimum plant girth $\left(4.37 \mathrm{~cm}^{2}\right)($ Table 1$)$. It is evident from the results (Table 2) that plant girth, leaf area, leaf sheath hairiness and leaf thickness showed highly significant correlation with pest infestation with r-value $0.139,0.181,0.287$ and 0.381 , respectively. Plant girth contributes $2 \%$ while leaf area contributes $6 \%$. The contribution of leaf sheath hairiness and leaf thickness was $35.6 \%$ in fluctuating the pest infestation. The analysis of variance exhibited that all varieties were highly significant in terms of plant girth and leaf area showed significant impact on the pest infestation while leaf sheath hairiness and leaf thickness were important factors which showed maximum per unit change in population fluctuation of the pest. The maximum leaf area $466 \mathrm{~cm}^{2}$ recorded in variety SPF-234 and the variety US-824 showed minimum leaf area (318 $\mathrm{cm}^{2}$ ) (Table 3).

\section{Role of Qualitative Factors on the Shoot Borer Infestation}

The data regarding qualitative factors were subjected to mean performance, correlation coefficient values and multiple linear regression models to find out the impact of these factors on the infestation. The maximum percentage of brix was recorded in variety US$312(23.43 \%)$ and the variety SPF-234 showed minimum percentage of $18.46 \%$. The POL percentage in US-312 was higher $(20.93 \%)$ while SPF-234 showed minimum POL percentage (15.27\%). The variety US-718 showed maximum (15.84\%) of CCS while variety SPF-234 showed minimum percentage of CCS (11.08\%). The maximum fiber 
contents were found in US-676 (13.68\%) while US-1491 showed minimum percentage of fiber contents $(11.99 \%)$. The sugar recovery $(11.74 \%$ and $11.52 \%)$ was maximum in US-312 and US-718, respectively while the variety SPF-234 showed minimum percentage of recovery $(8.12 \%)$ (Table 4$)$.

It is evident from the results (Table 2) that Brix and POL percentage showed significant correlation with pest infestation with $\mathrm{r}$-values 0.650 and 0.683 , respectively while the fiber and CCS also showed positive and significant correlation with shoot borer infestation with r-values 0.291 and 0.643 , respectively. From the results it is concluded that that brix and POL were the important factors which showed significant effect on the infestation. Similarly, fiber contents contributed minimum $(8.5 \%)$ towards the infestation while the brix contributed $44.6 \%$. The POL contribution was recorded $58.5 \%$ when POL was added (Table 5). The $100 \mathrm{R}^{2}$ value was reached to $61.4 \%$ when all the factors computed together. From these results it is concluded that fiber contents showed negligible impact while other qualitative factors showed maximum per unit change in population fluctuation of the pest infestation.

Table 1. Comparison of means for the data regarding plant girth, leaf thickness, leaf sheath hairiness and leaf area in various chosen varieties of sugarcane

\begin{tabular}{c|c|c|c|c}
\hline Varieties & Plant Girth $(\mathbf{c m})$ & Leaf Thickness $(\mathbf{m m})$ & $\begin{array}{c}\text { Leaf Sheath Hairiness } \\
\mathbf{( c m}^{\mathbf{2}}\end{array}$ & $\begin{array}{c}\text { Leaf Area } \\
\mathbf{( c m}^{\mathbf{}} \mathbf{)}\end{array}$ \\
\hline US-676 & $5.13 \pm 0.035 \mathrm{~B}$ & $0.627 \pm 0.007 \mathrm{BC}$ & $63.02 \pm 2.76 \mathrm{D}$ & $461.84 \pm 1.85 \mathrm{~A}$ \\
US-133 & $4.73 \pm 0.052 \mathrm{CD}$ & $0.617 \pm 0.012 \mathrm{CD}$ & $82.54 \pm 1.32 \mathrm{C}$ & $337.84 \pm 3.55 \mathrm{~F}$ \\
US-312 & $5.23 \pm 0.052 \mathrm{AB}$ & $0.617 \pm 0.012 \mathrm{CD}$ & $76.66 \pm 2.00 \mathrm{C}$ & $359.11 \pm 1.34 \mathrm{E}$ \\
SPF-234 & $4.56 \pm 0.205 \mathrm{CDE}$ & $0.597 \pm 0.009 \mathrm{DE}$ & $53.42 \pm 2.65 \mathrm{E}$ & $466.57 \pm 1.14 \mathrm{~A}$ \\
US-1491 & $5.43 \pm 0.145 \mathrm{AB}$ & $0.637 \pm 0.003 \mathrm{ABC}$ & $95.25 \pm 1.74 \mathrm{~B}$ & $382.99 \pm 1.82 \mathrm{D}$ \\
US-824 & $5.47 \pm 0.085 \mathrm{~A}$ & $0.647 \pm 0.009 \mathrm{AB}$ & $77.76 \pm 1.75 \mathrm{C}$ & $318.50 \pm 3.45 \mathrm{G}$ \\
CPF-246 & $4.37 \pm 0.059 \mathrm{E}$ & $0.660 \pm 0.006 \mathrm{~A}$ & $102.42 \pm 1.11 \mathrm{~A}$ & $414.99 \pm 1.27 \mathrm{~B}$ \\
US-718 & $4.78 \pm 0.074 \mathrm{C}$ & $0.613 \pm 0.003 \mathrm{CD}$ & $81.57 \pm 1.89 \mathrm{C}$ & $394.45 \pm 1.97 \mathrm{C}$ \\
CPF-237 & $4.44 \pm 0.067 \mathrm{DE}$ & $0.583 \pm 0.003 \mathrm{E}$ & $95.73 \pm 0.69 \mathrm{~B}$ & $323.31 \pm 2.43 \mathrm{G}$ \\
\hline
\end{tabular}

In a column, means with different letters are statistically significant as determined by Tukey HSD test at $\mathrm{P} \leq 0.05$

Table 2. Correlation between Infestation and Various Sugars Physico-Morphic and Qualitative Factors

\begin{tabular}{c|c}
\hline Factors & Correlation $(\mathbf{r})$ \\
\hline Fiber & $0.291^{*}$ \\
Brix & $0.650^{*}$ \\
POL & $0.683^{*}$ \\
CCS & $0.643^{*}$ \\
Recovery & $0.547^{*}$ \\
Carbohydrate & $0.288^{*}$ \\
Fat & $0.095^{*}$ \\
Moisture & $0.239^{*}$ \\
Plant Girth & $0.139^{* *}$ \\
Leaf Area & $0.181^{* *}$ \\
Leaf sheath hairiness & $0.287^{* *}$ \\
Leaf Thickness & $0.381^{* *}$ \\
\hline
\end{tabular}

\footnotetext{
$*=$ Significant at $\mathrm{P} \leq 0.05 * *=$ highly Significant at $\mathrm{P} \leq 0.05$
} 
Table 3. Regression analysis for Physico-Morphic plant factors

\begin{tabular}{c|c}
\hline Regression Equation & $\mathbf{R}^{\mathbf{2}}$ \\
\hline $\mathrm{Y}=16.2-0.188 \mathrm{X}_{1}$ & 0.020 \\
$\mathrm{Y}=17.4-0.248 \mathrm{X}_{1}-0.00223 \mathrm{X} 2$ & 0.066 \\
$\mathrm{Y}=22.1-0.510 \mathrm{X}_{1}-0.00621 \mathrm{X}_{2}-0.0240 \mathrm{X}_{3}$ & 0.356 \\
$\mathrm{Y}=22.0-0.520 \mathrm{X}_{1}-0.00629 \mathrm{X}_{2}-0.0244 \mathrm{X}_{3}+0.3 \mathrm{X}_{4}$ & 0.356 \\
\hline
\end{tabular}

$\mathrm{Y}=$ Infestation, $\mathrm{X}_{1}=$ Plant Girth, $\mathrm{X}_{2}=$ Leaf Area, $\mathrm{X}_{3}=$ Leaf sheath hairiness, $\mathrm{X}_{4}=$ Leaf Thickness, $\mathrm{R}^{2}=$ Coefficient of Determination

Table 4. Comparison of means for the data regarding Brix, Pol, Ccs, Fiber, Recovery, Fat, Moisture contents and Carbohydrate in various chosen varieties of sugarcane

\begin{tabular}{c|c|c|c|c|c|c|c|c}
\hline Varieties & Brix (\%) & POL $(\%)$ & CCS\% & Fiber (\%) & Recovery (\%) & Fat (\%) & $\begin{array}{c}\text { Moisture } \\
\text { Content (\%) })\end{array}$ & $\begin{array}{c}\text { Carbohydrates } \\
(\%)\end{array}$ \\
\hline US-676 & $21.04 \pm 0.48$ & $18.00 \pm 0.07^{\mathrm{D}}$ & $13.18 \pm 0.17^{\mathrm{E}}$ & $13.68 \pm 0.08^{\mathrm{A}}$ & $10.16 \pm 0.18^{\mathrm{C}}$ & $2.16 \pm 0.009^{\mathrm{AB}}$ & $78.35 \pm 0.037^{\mathrm{CD}}$ & $49.55 \pm 0.11^{\mathrm{D}}$ \\
US-133 & $22.50 \pm 0.28$ & $19.83 \pm 0.38^{\mathrm{AB}}$ & $14.99 \pm 0.34^{\mathrm{ABC}}$ & $12.74 \pm 0.10^{\mathrm{B}}$ & $11.15 \pm 0.16^{\mathrm{B}}$ & $1.99 \pm 0.024^{\mathrm{D}}$ & $78.04 \pm 0.042^{\mathrm{E}}$ & $52.57 \pm 0.19^{\mathrm{A}}$ \\
US-312 & $23.43 \pm 0.47$ & $20.93 \pm 0.34^{\mathrm{A}}$ & $15.66 \pm 0.37^{\mathrm{A}}$ & $13.47 \pm 0.14^{\mathrm{A}}$ & $11.74 \pm 0.13^{\mathrm{A}}$ & $2.12 \pm 0.027^{\mathrm{BC}}$ & $78.65 \pm 0.137^{\mathrm{A}}$ & $49.46 \pm 0.11^{\mathrm{D}}$ \\
SPF-234 & $18.46 \pm 0.75$ & $15.27 \pm 0.30^{\mathrm{E}}$ & $11.08 \pm 0.26^{\mathrm{F}}$ & $12.59 \pm 0.16^{\mathrm{B}}$ & $8.12 \pm 0.12^{\mathrm{D}}$ & $2.20 \pm 0.022^{\mathrm{A}}$ & $78.60 \pm 0.023^{\mathrm{AB}}$ & $50.32 \pm 0.16^{\mathrm{C}}$ \\
US-1491 & $23.06 \pm 0.10$ & $20.16 \pm 0.43^{\mathrm{AB}}$ & $15.30 \pm 0.53^{\mathrm{AB}}$ & $11.99 \pm 0.05^{\mathrm{C}}$ & $11.29 \pm 0.14^{\mathrm{AB}}$ & $1.99 \pm 0.024^{\mathrm{D}}$ & $78.32 \pm 0.055^{\mathrm{CD}}$ & $47.57 \pm 0.22^{\mathrm{F}}$ \\
US-824 & $21.41 \pm 0.74$ & $18.50 \pm 0.34^{\mathrm{CD}}$ & $13.66 \pm 0.17^{\mathrm{DE}}$ & $12.64 \pm 0.07^{\mathrm{B}}$ & $10.05 \pm 0.14^{\mathrm{C}}$ & $2.17 \pm 0.020^{\mathrm{AB}}$ & $78.51 \pm 0.018^{\mathrm{ABC}}$ & $48.42 \pm 0.24^{\mathrm{E}}$ \\
CPF-246 & $22.68 \pm 0.34$ & $19.93 \pm 0.51^{\mathrm{AB}}$ & $14.17 \pm 0.64^{\mathrm{CDE}}$ & $13.60 \pm 0.10^{\mathrm{A}}$ & $10.55 \pm 0.29^{\mathrm{C}}$ & $2.06 \pm 0.023^{\mathrm{CD}}$ & $78.37 \pm 0.035^{\mathrm{CD}}$ & $51.12 \pm 0.40^{\mathrm{B}}$ \\
US-718 & $23.33 \pm 0.27$ & $20.92 \pm 0.31^{\mathrm{A}}$ & $15.84 \pm 0.28^{\mathrm{A}}$ & $13.45 \pm 0.06^{\mathrm{A}}$ & $11.52 \pm 0.16^{\mathrm{AB}}$ & $2.18 \pm 0.009^{\mathrm{B}}$ & $78.42 \pm 0.025^{\mathrm{BCD}}$ & $50.32 \pm 0.09^{\mathrm{C}}$ \\
CPF-237 & $22.34 \pm 0.65$ & $19.34 \pm 0.44^{\mathrm{BC}}$ & $14.31 \pm 0.27^{\mathrm{BCD}}$ & $13.52 \pm 0.22^{\mathrm{A}}$ & $10.42 \pm 0.14^{\mathrm{C}}$ & $2.00 \pm 0.023^{\mathrm{D}}$ & $78.26 \pm 0.020^{\mathrm{D}}$ & $52.34 \pm 0.09^{\mathrm{A}}$ \\
\hline
\end{tabular}

$\pm(\mathrm{SE})=$ Standard error

Table 5. Regression analysis for sugar Qualitative factors

\begin{tabular}{c|c}
\hline Regression Equation & $\mathbf{R}^{2}$ \\
\hline $\mathrm{Y}=18.9-0.275 \mathrm{X}_{1}$ & 0.085 \\
$\mathrm{Y}=22.1-0.147 \mathrm{X}_{1}-0.223 \mathrm{X}_{2}$ & 0.446 \\
$\mathrm{Y}=13.4-0.073 \mathrm{X}_{1}+1.33 \mathrm{X}_{2}-1.38 \mathrm{X}_{3}$ & 0.585 \\
$\mathrm{Y}=11.6+0.056 \mathrm{X}_{1}+1.52 \mathrm{X}_{2}-1.91 \mathrm{X}_{3}+0.434 \mathrm{X}_{4}$ & 0.614 \\
$\mathrm{Y}=12.3+0.061 \mathrm{X}_{1}+1.64 \mathrm{X}_{2}-1.97 \mathrm{X}_{3}+0.454 \mathrm{X}_{4}+0.195 \mathrm{X}_{5}$ & 0.632 \\
$\mathrm{Y}=11.3+0.073 \mathrm{X}_{1}+1.87 \mathrm{X}_{2}-1.99 \mathrm{X}_{3}+0.488 \mathrm{X}_{4}+0.123 \mathrm{X}_{5}+0.074 \mathrm{X}_{6}$ & 0.657 \\
$\mathrm{Y}=13.2+0.086 \mathrm{X}_{1}+2.11 \mathrm{X}_{2}-2.09 \mathrm{X}_{3}+0.668 \mathrm{X}_{4}+0.1373 \mathrm{X}_{5}+0.086 \mathrm{X}_{6}$ & 0.682 \\
$\mathrm{Y}=12.5+0.098 \mathrm{X}_{1}+2.43 \mathrm{X}_{2}-2.89 \mathrm{X}_{3}+0.712 \mathrm{X}_{4}+0.1421 \mathrm{X}_{5}+0.121 \mathrm{X}_{6}+0.253 \mathrm{X}_{7}$ & 0.713 \\
\hline
\end{tabular}

$\mathrm{Y}=$ Infestation $(\%), \mathrm{X}_{1}=$ Fiber, $\mathrm{X}_{2}=$ Brix, $\mathrm{X}_{3}=\mathrm{POL}, \mathrm{X}_{4}=$ Commercial Cane Sugar $(\mathrm{CCS})$, $\mathrm{X}_{5}=$ Recovery, $\mathrm{X}_{6}=$ Fat, $\mathrm{X}_{6}=$ Moisture, $\mathrm{X}_{7}=$ Carbohydrate, $\mathrm{R}^{2}=$ Coefficient of Determination

\section{Discussion}

The performance of all varieties in terms of morphological plant factors like plant girth, leaf area, leaf sheath hairiness and leaf thickness showed highly significant interaction towards the borer infestation. The present findings are comparable with those of Khliq et al. (2005) who reported that leaf thickness, cane girth and leaf area showed positive and significant correlation with borer infestation. Significant differences were documented among all the trait for recovery. The maximum recovery was exhibited by the trait US-718 whereas the lowest was observed for the trait SPF-234. Similar results were also reported by earlier research of Sarwar et al. (2011). Khan et al. (2004) reported 
that there was no relation between plant girth and shoot borer infestation. Cornelissen and Fernandes (2001) described that the absorption of sugars in leaves affects the area of leaf damaged by herbivores in Bauhinia brevipes. The accessibility of plants increases with the quantity of reducing sugars, and resistance increases with organic acids according to Comes (1916). The quantity of reducing sugars, affected by insects which increased the vegetable tissues, as a result caused reduction in the organic acids. Correlation among morphological characters may reproduce biological processes that are of considerable evolutionary interest, correlation can be the result of functional, genetic and physiological or developmental characters (Mehmood et al., 2000; Ali et al., 2013, 2014, 2016).

The results are similar in with Baloch et al. (2005) reported that factors like fiber, brix, POL and CCS showed significant variations and reduced the damage. Brix and POL percentage showed significant correlation with pest infestation, while fiber contents and CCS showed significant correlation with infestation. The qualitative parameters after brix \% and POL\% in (Table 5) showed significant differences among the brix\% and POL\%. The lowest brix\% was recorded for SPF-234 whereas highest was displayed by US-312. The maximum POL\% was showed by US-312 and US-318 whereas the minimum POL\% was showed by US-676. These results are in contrary with the findings of Panhwar et al. (2004). The present results are similar with those of Khan et al. (2004) who reported that there is positive relation between brix and shoot borer infestation. The present findings are partially comparable with those of Gupta and Singh (1997) who reported that brix, POL, fiber contents and CCS are affected by the borer infestation. Chang and Wang (1995) reported that sugar contents, brix and sugar purity are heavily affected by sugarcane borer. The CCS, POL\% and brix contents showed significant effect on the borer infestation Khaliq et al. (2005).

\section{Conclusion}

It was concluded from present study that varieties US-312, 1491, 718, 133 and CPF-246 could be used to minimize the losses caused by shoot borer pest infestation and all these varieties showed significant qualitative and quantitative interaction towards Chilo infuscatellus.

Acknowledgements. The authors are thankful for financial support provided by Department of Entomology, University of Agriculture Faisalabad and Higher Education Commission of Pakistan.

\section{REFERENCES}

[1] Ali, Q., Ahsan, M., Ali, F., Aslam, M., Khan, N. H., Munzoor, M., Mustafa, H. S. B., Muhammad, S. (2013): Heritability, heterosis and heterobeltiosis studies for morphological traits of maize (Zea mays L.) seedlings. - Advancements in Life sciences 1(1): 52-63.

[2] Ali, Q., Ali, A., Waseem, M., Muzaffar, A., Ahmad, S., Ali, S., Awan, M., Samiullah, T., Nasir, I., Tayyab, H. (2014): Correlation analysis for morpho-physiological traits of maize (Zea mays L.). - Life Science Journal 11: 9-13.

[3] Ali, Q., Ahsan, M., Malook, S., Kanwal, N., Ali, F., Ali, A., Ahmed, W., Ishfaq, M., Saleem, M. (2016): Screening for drought tolerance: comparison of maize hybrids under water deficit condition. - Advancements in Life Sciences 3(2): 51-58.

[4] Anonymous (2016-17): Economic Survey of Pakistan. - Govt. Pak. Eco. Advisory Wing, Finance Div. Islamabad. 
[5] Anwar, M. S., Ali, H. W., Ahmad, A., Chatta, A. A. (2004): Integrated management of sugarcane insects. - Journal of Pakistan Sugarcane 19(6): 28-31.

[6] AOAC. (1996): Methods of Analyses. - 15th Association of Official Analytical Chemistry, Arlington, VA.: 40-50, 237-238.

[7] Baloch, F. M., Soomro, N. A., Usmanikhail, M. U., Tunio, G. S., Baloch, L. M. (2005): Growth and yield behaviour of different sugarcane varieties under agro ecological conditions of lower Sindh. - Journal of Pakistan Sugarcane 4(3): 287-291.

[8] Chang, Y. S., Wang, K. R. (1995): Statistical analysis of the effect of sugarcane borer damage on cane juice quality. - Report of Taiwan Sugar Research Institute 149(06): 1-12.

[9] Comes, O. (1916): La Profilaxia en Patoligia Vegethl, Reale Institutd, Incorraggiamentdi Napoli, Naples. - Biology and Agriculture 9(102): 173.

[10] Cornelissen, T., Fernandes, G. W. (2001): Defense, growth, and nutrient allocation in the tropical shrub Bauhinia brevipes (Leguminosae). - Australian Ecology 26: 246-253.

[11] Goebel, F. R. (1999): Biocontrol of Chilo sacchariphagus (Lepidoptera: Crambidae) a key pest of sugarcane: Lessons from the past and future prospects. - Unité de Lutte Biologique and 400 Route des Chappes, 06410 Sophia Antipolis, France.

[12] Goettel, M. S. (1999): Directory of Microbial Control Products and Services, Division on microbial Control. - Society for Invertebrate Pathology, Division on Microbial Control, Gainesville, USA, 81.

[13] Gupta, M. K., Singh, S. N. (1997): Qualitative losses in sugarcane by plassy borer and top borer damage. - Indian Sugar 47(4): 275-277.

[14] Kfir, R., Overholt, W. A., Khan, Z. R., Polaszek, A. (2002): Biology and management of economically important lepidopteron cereal stem Borers in Africa. - Annuals Reviews of Entomology 47(26): 701-31.

[15] Khaliq, M. A., Ashfaq, M., Ali, A. (2005): Chemical plant factors affecting resistance in sugarcane against Scirpophaga nivella. - Journal of Pakistan Science and Technology 27(2): 67-71.

[16] Khan, I. A. (2004): Performance of promising sugarcane clone for yield and quality traits in different ecological zones of Sindh. - Pakistan Journal of Botany 4(1): 92-95.

[17] Kumarasinghe, N. C. (1999): Insect fauna associated with sugarcane plantations in Srilanka Division of Pest Management. - Sugarcane Research Institute, Uda Walawe, Srilanka.

[18] Mahmood, T., Nazir, M. S., Ashfaq, M., Chodhery, N. A. (2000): Correlation in sugarcane. - Journal of Agriculture Research 28: 359-63.

[19] Meade, G. P., Chen, J. C. P. (1977): Cane Sugar Hand Book (10th). - Wiley Inter Science, John Wiley and Sons, New York, PP. 947.

[20] Panhwar, R. N., Keerio, H. K., Keerio, A. R. (2004): Evaluation of sugarcane genotypes for yield and yield contributing traits under thatta conditions. - Pakistan Journal of Agricultural Research 18(1): 34-36.

[21] Payne, J. H. (1968): Sugarcane factory analytical control. - Elsevier pub. Co. Amsterdam, London, New York.

[22] Sarwar, M. A., Fiaz, A. N., Hussain, S., Chattha, A. A. (2011): Evaluation of approved sugarcane varieties through hydraulic press method. - International Journal of Agriculture and Applied Sciences 3(1): 14-17.

[23] Shahid, M. R. (2007): Effectiveness of Trichogramma chilonis (ishii) (Hymenoptera: Trichogrammatidae) against sugarcane stem borer (Chilo infuscatellus Snellen) (Lepidoptera: Pyralidae). - Pakistan Journal of Entomology 29(2): 141-146.

[24] Wang, J., Wang, W., Rong, W., Zheng, H., Gao, G. (2017): Molecular Detection of Chilo infuscatellus. - Journal of Insect Science 17(05): 102.

[25] Zia, H. A. (2007): Bio control of insect pests of sugarcane (Saccharum sp). - Journal of Pakistan Sugarcane 22(5): 13-22. 